\title{
Infant male circumcision: An evidence-based policy statement
}

\author{
Brian J. Morris ${ }^{1^{*}}$, Alex D. Wodak ${ }^{2}$, Adrian Mindel ${ }^{3}$, Leslie Schrieber ${ }^{4}$, Karen A. Duggan ${ }^{5}$, \\ Anthony Dilley ${ }^{6}$, Robin J. Willcourt ${ }^{7}$, Michael Lowy ${ }^{8}$, David A. Cooper ${ }^{9}$, Eugenie R. Lumbers ${ }^{10}$, \\ C. Terry Russell ${ }^{11}$, Stephen R. Leeder ${ }^{12}$ \\ ${ }^{1}$ School of Medical Sciences and Bosch Institute, The University of Sydney, Sydney, Australia; \\ *Corresponding Author: brian.morris@sydney.edu.au \\ ${ }^{2}$ Alcohol and Drug Service, St Vincents Hospital, Sydney, Australia \\ ${ }^{3}$ The Sexually Transmitted Infections Research Centre, Westmead Hospital, University of Sydney, Sydney, Australia \\ ${ }^{4}$ Sydney Medical School, University of Sydney at Royal North Shore Hospital, Sydney, Australia \\ ${ }^{5}$ Vectus Biosystems, North Ryde, Australia \\ ${ }^{6}$ Department of Paediatrics, Sydney Children's Hospital, Randwick, Sydney, Australia \\ ${ }^{7}$ Pregnancy Advisory Centre, The Queen Elizabeth Hospital, Adelaide, Australia \\ ${ }^{8}$ Sydney Men's Health University of New South Wales and University of Notre Dame Sydney, Sydney, Australia \\ ${ }^{9}$ The Kirby Institute for Infection and Immunity in Society (Formerly the National Centre in HIV Epidemiology and Clinical Re- \\ search), University of New South Wales and St Vincent's Hospital, Sydney, Australia \\ ${ }^{10}$ School of Biomedical Sciences \& Mothers \& Babies Research Centre, University of Newcastle \& Hunter Medical Research Insti- \\ tute, John Hunter Hospital, Newcastle, Australia \\ ${ }^{11}$ Circumcision Foundation of Australia, Russell Medical Centre, Brisbane, Australia \\ ${ }^{12}$ Menzies Centre for Health Policy, School of Public Health, University of Sydney, Sydney, Australia
}

Received 22 October 2011; revised 29 November 2011; accepted 14 December 2011

\section{ABSTRACT}

Here we review the international evidence for benefits and risks of infant male circumcision (MC) and use this to develop an evidence-based policy statement for a developed nation setting, focusing on Australia. Evidence from good quality studies that include meta-analyses and randomized controlled trials showed that MC provides strong protection against: urinary tract infections and, in infancy, renal parenchymal disease; phimosis; paraphimosis; balanoposthitis; foreskin tearing; some heterosexually transmitted infections including HPV, HSV-2, trichomonas, HIV, and genital ulcer disease; thrush; inferior hygiene; penile cancer and possibly prostate cancer. In women, circumcision of the male partner protects against HPV, HSV-2, cervical cancer, bacterial vaginosis, and possibly Chlamydia. MC has no adverse effect on sexual function, sensitivity, penile sensation or satisfaction and may enhance the male sexual experience. Adverse effects are uncommon $(<1 \%)$, and virtually all are minor and easily treated. For maximum benefits, safety, convenience and cost savings, MC should be performed in infancy and with local anesthesia. A risk-benefit analysis shows benefits exceed risks by a large margin. Over their lifetime up to half of uncircumcised males will suffer a medical condition as a result of retaining their foreskin. The ethics of infant MC and childhood vaccination are comparable. Our analysis finds MC is beneficial, safe and cost-effective, and should optimally be performed in infancy. In the interests of public health and individual wellbeing, adequate parental education, and steps to facilitate access and affordability should be encouraged in developed countries.

Keywords: Male Circumcision; Public Health; Infant Infections; Sexually Transmitted Infections; Cervical Cancer

\section{INTRODUCTION}

The Circumcision Foundation of Australia was formed in 2010 to provide education, clinical training and commentary on male circumcision (MC) [1]. At present there is an absence of evidence-based policy on this topic in developed countries such as Australia. This, despite the increase in recent years in the quality and quantity of evidence in support of medical MC as a result of numerous studies that have included wide-ranging findings from large randomized controlled trials (RCTs) and meta-analyses. Calls have been made in Australia [2,3], the USA [4,5], 
and the UK [6] for infant MC to be encouraged because of the considerable benefits it confers to public health and individual wellbeing [7]. Until the 1970s infant MC was routine in for Australia, but the rate may now be less than $20 \%$, despite increases in the two most populous states over the past decade [8]. This further highlights the need for evidence-based policy. Here we provide a comprehensive up-to-date review of the diversity of benefits and the risks of infant MC in formulation of such a policy.

\section{METHODS}

A detailed examination was conducted of references from the first author's lifetime collection, most of which had been accumulated over the past two decades from weekly alerts based on the key-word "circumcision" from NCBI PubMed over the past 5 years and Current Contents prior to that. We then evaluated the quality of the evidence using the Scottish Intercollegiate Guidelines Network (SIGN) grading system for evidence-based guidelines [9], which ranges from $1++$ (highest) to 4 (lowest).

\section{RESULTS AND DISCUSSION}

\subsection{Urinary Tract Infection (UTI)}

The highest prevalence and greatest severity of UTIs is in the first 6 months of life $[10,11]$. UTIs are common [12] and can lead to significant morbidity [13]. Prevalence is $1 \%-4 \%$ in uncircumcised boys, and $0.1 \%-0.2 \%$ in circumcised boys [11,14-18]. The protective effect of MC was confirmed by a RCT, which noted a 96\% decrease in UTI after treatment by MC at age 6 months [19]. Cumulative prevalence to age 5 was $6 \%$ in uncircumcised boys in Western Sydney, with only 2 circumcised boys experiencing a UTI [20]. Although prevalence decreases after infancy [21], there is "no evidence that the patient's age modified the protective effect of circumcision status on the development of UTI” [20]. Cumulative prevalence to age 16 was $3.6 \%$ in uncircumcised boys in a UK study [22]. In US men, circumcision reduced UTI prevalence by 5.6 fold [23], and over the lifetime cumulative incidence of UTI in the uncircumcised is 1 in 4 [24].

UTI may lead to an acute febrile condition and significant symptoms such as severe pain. Often the cause of the fever is undiagnosed. If the boy is uncircumcised a UTI should be suspected. Boys presenting with fever have UTI as the cause in over $20 \%$ of cases if uncircumcised, but only $2 \%$ if circumcised $[25,26]$. In febrile infants bacteriuria is seen in $36 \%$ of uncircumcised boys, indicating that a UTI as the likely cause of fever, compared with only $1.6 \%$ of circumcised boys, a 23-fold difference [27]. The American Academy of Pediatrics Subcommittee on Urinary Tract Infections recommends a urine culture for any child under 2 with unexplained fever. Most boys are hospitalized and given parenteral antibiotics.
Acute pyelonephritis is seen in $90 \%$ of infants with a febrile UTI [28], 34\% - 86\% of whom exhibit renal parenchymal defects [21,29], and 36\% - 52\% will show renal scarring [28]. This exposes them to serious, life-threatening conditions later in life [30], including end-stage renal disease in $10 \%$ [31].

Recurrence of UTI occurs in 35\% of UTI cases in infant males. Urinary tract abnormalities increase the risk of recurrent UTI, but $10 \%$ of UTIs occur in the absence of a urinary tract abnormality [20], nonretractile foreskin and acute pyelonephritis being the biggest risk factors for recurrence [32]. MC moreover protects against recurrence [33]. In $36 \%$ of boys acute pyelonephritis is seen in the absence of vesicoureteric reflux (VUR) [32]. Pyelonephritis can lead to renal scarring, and most children who develop renal scarring do not have VUR [34]. Parenchymal infection and inflammation, rather than VUR, is a prerequisite for renal scarring [34]. Advice that MC only be recommended in boys with recurrent UTI or VUR has been criticized as flawed [35].

Because UTIs are often associated with long-term morbidity and potential mortality [12], prevention by circumcision is recommended.

\subsection{Hygiene}

A circumcised penis is generally easier to clean. Even if the male or his parents routinely retract the foreskin to clean under it, pathogenic bacteria [36] quickly return [37,38]. Better hygiene is often stated as the main reason why Australian parents have wanted their baby boy circumcised [39]. Penile hygiene has been found to be inferior in uncircumcised schoolboys [37,40] and London men [41], especially those with long foreskins [42]. Starting in adolescence, smegma accumulates under all foreskins that are not easily retractable. Yeast and some bacteria, notably Mycobacterium smegmatis, cause smegma to have an offensive odour $[43,44]$.

\subsection{Inflammatory Dermatoses}

Inflammation of the penis, in the form of balanitis, posthitis and balanoposthitis, is common in uncircumcised males [3]. A frequent cause is Candida spp. infection [45]. A meta-analysis of 12 studies found that MC reduced balanitis by 3-fold (OR 0.32; 95\% CI 0.20 - 0.51) (J.H. Waskett, unpublished). In children, balanitis affected 5.9\% of uncircumcised boys in one survey [46] and 14\% in another [47]. A cross-sectional study of randomly selected dermatology patients found balanitis in $13 \%$ of uncircumcised, but only $2.3 \%$ of circumcised men [48]. Treatment of balanitis was the reason why $29 \%$ of those men had to be circumcised.

\subsection{Phimosis and Paraphimosis}

Phimosis is the narrowing of the foreskin orifice, some- 
times to a pinpoint, so as to prevent normal retraction of the foreskin over the glans [49]. While this state is normal under age 3, if still present by age 6 it is regarded as a problem. Clinical observations and survey data reveal prevalence of phimosis in youths and men is $8 \%$ - 14\% (see reviews [3,7]). Phimosis may arise from physiological adhesion of the foreskin to the glans, or from fibrous adhesions due to acquired pathology such as balanitis xerotica obliterans (BXO) [50] that causes secondary cicatrization of the foreskin orifice. BXO-induced phimosis presents most commonly at age 8 - 10 years [50]. Once thought to be rare and a disorder presenting in adulthood, $\mathrm{BXO}$ is now regarded as common in boys, in whom treatment by MC is advised to prevent the complications that occur later in life [51]. Of 13 studies, BXO was the cause of phimosis in $25 \%$ of cases [7]. Although treatment by a month or so of continued application of steroid creams can be effective in the short-term, a RCT showed that in the long-term recurrence of phimosis is frequent, requiring retreatment or circumcision [52].

Paraphimosis refers to an inability to return the foreskin after retraction over the glans. This painful condition causes a severe diminution of blood flow to the glans, and its occurrence represents a medical emergency since gangrene of the distal penis can occur [49].

\subsection{Sexually Transmitted Infections}

Male circumcision protects against many, but not all, sexually transmitted infections (STIs) [53]. In the case of syphilis, genital herpes (HSV-2) and chancroid, a metaanalysis of 26 studies, including 2 from Australia, found lower prevalence in circumcised men [54]. For oncogenic $\mathrm{HPV}$, a recent meta-analysis of 23 studies, including 10 from the USA, found overall prevalence of DNA for such viral types to be $41 \%$ lower overall in circumcised men, but $53 \%$ lower on the glans/corona and $65 \%$ lower in the urethra [55]. Longitudinal studies in two New Zealand populations found self-reported lifetime STIs was higher in uncircumcised men in one [56], but no different in another [57]. The latter group found no difference in HSV-2 [58] or HPV [59] seroprevalence. Seroprevalence indicates previous exposure, rather than incident infection, which is higher in uncircumcised men possibly because circumcised men clear HPV faster [55,60-62]. Secondary analyses from high quality RCTs support the protection afforded by MC against incident HSV-2 [63,64] and HPV [61,65-70]. This included showing 97\% protection against HPV-related flat penile lesions [71]. A US study saw 64\% lower HSV-1 seroprevalence in circumcised men [72]. MC also protected against genital ulcer disease (GUD) [73,74], including in HSV-2 seronegative men in one trial [75]. MC does not protect against sexually transmitted urethritis in men [76].

A strong case can be made for infant MC in developed countries in reducing some STIs, because: 1) There is an epidemic of oncogenic HPV and HSV-2, with seroprevalence in young men of 25\% [59] and 8\% [58,77] for each respective virus; 2) In the case of Australia, MC prevalence is decreasing as males not circumcised in infancy continue to enter sexually active age groups [78]; 3) The average number of sexual partners and STI prevalence is rising [79], but condom use was not in senior high school [79] and high-risk [80] adolescents [79]; 4) Condoms, while helpful, vary in efficacy against different STIs, being only partially protective against HPV [59,81-83] and HSV-2 [84], and are not used at all or are used only sporadically by many people [57,85-89]. Condoms have to be applied each time, and are therefore often not in place during sex, whereas MC is always present; 5) Infancy is the best time to perform MC as it ensures the male is already protected by the time he becomes sexually active.

\subsection{HIV}

Male circumcision affords over $60 \%$ protection against HIV, as confirmed by 3 large RCTs [74,90,91] and later endorsed by a Cochrane review [92]. Meta-analyses of observational studies found protection to be similar [93-95] or stronger [96] than in the RCTs. The epidemiological findings are supported by biological evidence [97]. As pointed out in one of the meta-analyses [95], MC satisfies 6 of the 9 criteria of causality outlined by Sir A.B. Hill [98]—-strength of association, consistency, temporality, coherence, biological plausibility, and experiment. Follow-up data indicate an ongoing increase in the protective effect of MC [99-101] to $73 \%$ after 5 years [101]. This means that MC is as effective in HIV prevention as vaccines against influenza [102,103]. So “early stopping [of the RCTs] may have underestimated the effect [of MC]" [93]. Acceptance by the WHO and UNAIDS [104] has been followed by the large-scale implementation of MC in sub-Saharan Africa, early data revealing a protective effect of 76\% [105].

Although no data exist in Australia, the protective effect of MC against HIV infection from heterosexual contact is likely to be just as great as in the USA [106-108]. While such infections were negligible in the 1980s, this mode was responsible for $10 \%$ of new HIV diagnoses in the USA in 2010 [109] and 23\% (1185 cases) in Australia in 20052010 compared with 841 (20\%) in 2000-2004 [110]. After excluding infections acquired in a high prevalence country, there were $527 \mathrm{HIV}$ cases from heterosexual contact in 2000-2004, rising to 703 in 2005-2009, a 33\% increase (38\% in men and $28 \%$ in women) [110]. The highest proportion (31\%) was in Australian-born individuals. Such trends have led to calls for infant MC to be encouraged strongly in Australia [2]. Similarly, the Centers for Disease Control and Prevention (CDC) has affirmed the value of MC [4,111], finding infant MC to be cost-saving for HIV prevention in the USA [112]. 
For men who have sex with men (MSM), a Sydney study found MC had an 89\% protective effect in the 1 in 3 men who were insertive-only [113]. Such protection is supported by a meta-analysis of 18 studies [114] and a Cochrane review [115]. Circumcision of insertive-only MSM appeared, moreover, cost-effective for HIV prevention in Australia [116].

The cost of MC is a fraction of anti-retroviral treatment, the effectiveness of which requires strict compliance. Moreover, HIV prevention should be the primary focus of national policy. A cure, microbicide or a vaccine still appear to be a long way off [117].

\subsection{Cervical Cancer and STIs in Women}

Over 99\% of cervical cancers are caused by oncogenic HPV types [118] that are an epidemic worldwide, including Australia. A large multinational study found cervical cancer in monogamous women whose male partner was high-risk (had had six or more partners or was aged $<17$ at first sexual intercourse) to be 4 times higher if the man was uncircumcised, and twice as high if he had an intermediate sexual behavior risk index [83]. These categories encompass most men in Australia and other developed countries. A meta-analysis of 14 studies, two performed in Australia, confirmed the ability of MC to protect against cervical cancer [119]. An inverse relation exists between MC and cervical cancer prevalence across 118 countries [120]. Secondary data from a RCT showed MC reduces HPV acquisition in the female partners by at least 28\% [121].

Prophylactic vaccines against 2 of the over 15 types of oncogenic HPV are predicted to slowly reduce by half [122], but never eliminate, cervical cancer incidence over coming decades $[123,124]$. MC and vaccination should be regarded as synergistic for cervical cancer reduction. Vaccination of boys would have only limited benefits [123] and at present is not considered cost-effective [123-125].

HPV acquired during oral sex is an independent risk factor for some oropharyngeal cancers [126], which are rising in prevalence in the USA [127]. A study is needed of the MC status of the partner and such cancers.

MC also reduces by at least half the female partner's risk of HSV-2 [84,128,129], Chlamydia trachomatis [130], Trichomonas vaginalis [131], and bacterial vaginosis [131, 132]. Observational studies and secondary analyses of RCT data suggest transmission of HIV to women is $20 \%-46 \%$ lower if their male partner is circumcised [133-135].

\subsection{Penile Cancer and Prostate Cancer}

Lifetime risk of penile cancer in an uncircumcised man is approximately 1 in 1000 in the USA [136]. MC greatly reduces the risk of penile cancer $[137,138]$. Meta-analyses have shown major risk factors to be phimosis (12-fold increase) [137], balanitis (4-fold) [137], smegma (3-fold)
[137], and HPV (3 - 7 fold depending on type of squamous cell carcinoma) [139], all of which are more common in uncircumcised men [137]. Meta-analyses, that included studies from the USA, Australia and other countries, found MC halved the risk of oncogenic HPV infection [55,119,137]. Subsequent data from secondary analyses in the large HIV RCTs lends weight to these findings [61,65-70]. This includes demonstration in one of these of a $97 \%$ reduction in penile lesions caused by oncogenic HPV types [71]. One reason could be that circumcised men clear HPV infections more quickly, so reducing incident infection [55,60-62]. Particular attention should, however, be paid to the $~ 10 \%$ of uncircumcised men who have phimosis [3] as this is another major risk factor [137].

In the case of prostate cancer the evidence is mixed, yet sufficient data exist for a protective role that MC should be explored more extensively (see review [137]). If verified, MC could greatly reduce disease burden and associated costs [140].

\subsection{Effect of MC on Sexual Function, Sensation and Satisfaction}

Well conducted research studies have found no adverse effect of MC on penile sensitivity [141-144], sensation [145], sexual satisfaction [142,146], premature ejaculation [147], intravaginal ejaculatory latency time [148,149], and erectile function [78,142,150-152]. Such findings have now been supported by two large RCTs [153,154]. One of these found that MC improved sensation during sexual intercourse, leading to reports of better sex [154]. Two studies that found MC reduced risk of premature ejaculation was regarded by the men as a benefit $[155,166]$. A minority of studies has reported moderate adverse effects, but expert scrutiny [157-159] of these has revealed fundamental flaws that make the findings unreliable. There is some evidence that among 7 aspects of sexual function, for 6 there was no difference between men circumcised in infancy and those circumcised later, but for one, avoidance behavior, infant MC was more advantageous [160].

In the case of MSM, a study in Sydney found no differences in participation in insertive or receptive anal intercourse, difficulty in using condoms, or sexual problems such as loss of libido [161].

The female partners of men have found no adverse effect on their sexual experience after MC. A Mexican study found no change in sexual satisfaction, desire, pain during vaginal penetration or orgasm after their male partner had been circumcised [162]. In a RCT involving 455 women, $57 \%$ reported no change, while $40 \%$ reported an improvement in sexual satisfaction after circumcision of their male partner [163]. US studies have found that most women preferred the circumcised penis for sexual activity, hygiene and its appearance [164,165]. 


\subsection{Circumcision Techniques}

Circumcision involves firstly freeing the foreskin that is lightly adherent to the glans and then, by freehand methods or assistance from a device, the removal of the foreskin. An array of instruments is available to improve accuracy and safety [166]. The devices differ for infants, older children and adults [166]. In Australia the Plastibell device is commonly used for infant circumcisions, whereas in the USA the Gomco clamp tends to be preferred. The Plastibell is affixed, a ligature is applied, and the residual, necrotic foreskin and ring fall off several days later. The Gomco clamp and Mogen clamp allow the circumcision to be completed at the time. When circumcision is performed in infancy the ability of the inner and outer foreskin layers to adhere to each other means sutures are rarely needed and the scar that results is virtually invisible [167].

\subsection{Anesthesia}

Anesthesia should always be used. A local anesthetic is preferred as general anesthetics present unnecessary risks, including neurotoxicity and death [168], and are unnecessary [169]. The best time is early in infancy when the infant is less mobile [169]. Topical lidocaine-based creams such as LMX4 [170], dorsal penile nerve block [171] using a portable ultrasound scanner as a guide [172], penile ring block [173,174], and other methods can be used. While pain can be almost completely eliminated by local anesthetics, neonates exhibit lower pain scores than older infants [175], their response to pain is less for vaginal than caesarean delivery [176], and early exposure to noxious or stressful stimuli decreases pain sensitivity and behavior in adult life $[177,178]$. For MC without anesthetic there may be some short-tem memory of pain [179], but no credible evidence has been produced in support of any longterm memory of pain experienced in infancy.

\subsection{Complications}

In infancy, surgical complications for large published series range from $0.2 \%$ to $0.6 \%$ [15,180-183]. Higher rates of $2 \%$ - $10 \%$ have been reported in much older and smalller studies [184-186]. A recent systematic review found a median frequency of complications for neonatal or infant MC of $1.5 \%$ compared to $6 \%$ for studies of medical MC of children aged one year or older [187]. In both infants and older boys severe complications were extremely rare [187]. In men, RCT data indicated complication rates of $1.7 \%-3.8 \%$, none of the events being severe [74,90,91,188]. At any age, complications are virtually all minor and immediately treatable, with a satisfactory outcome. The higher complication rate after infancy is another argument for MC soon after birth.

Dubious Internet advice to circumcised men with sexual problems on recreation of a (pseudo) foreskin can result in damage to the penis [189].

\subsection{Ethical Considerations Regarding Neonatal Circumcision}

Circumcision should be regarded as a minor medical procedure. To maximize medical benefits and minimize risks and costs, circumcision should be performed in infancy. Parental choice in this regard is consistent with the rationale behind vaccinations, another minor medical procedure also performed before the child is old enough to give consent [190,191]. The authors of one bioethical analysis concluded that MC is appropriate for parental discretion [191]. An alternative view, based on right to autonomy, is that circumcision should be delayed until the male can decide for himself [192,193]. Other bioethicists and legal commentators argue that in view of the risks of not circumcising, infant MC is a justifiable public health measure [194,195].

As discussed, UTIs are common in infancy, as is the damage they cause to the still-growing kidney. Infant MC provides immediate protection against other common pediatric conditions such as phimosis, paraphimosis and balanoposthitis. After evaluating all of the evidence it is apparent that infant MC has a very favorable benefit versus risk, especially considering the diversity of other benefits that accumulate through the boy's lifetime (Table 1). MC in infancy is safer, simpler, quicker, cheaper, more convenient, healing is faster and the cosmetic result is superior to $\mathrm{MC}$ later. Other bioethicists have argued that MC in some contexts is ethically imperative, as to do otherwise would risk human lives [194]. Complications are, moreover, more common in older males than for neonatal or infant circumcision. Delay places children at higher risk of conditions that could be largely avoided if they had been circumcised in infancy. Later circumcision is also unrealistic and impractical [196]. The argument that adolescents or men should make the decision defaults to almost none of the men choosing to be circumcised, even when they know that there are clear benefits and would like to be circumcised [197].

In this era of preventive medicine infant MC is a logical decision that parents should be encouraged to make. The ethics of infant MC and childhood vaccination are comparable. The right of parents to decide whether or not to have their sons circumcised must be respected.

\section{CONCLUSION}

The current scientific evidence is more than adequate to support a recommendation of MC in Australia and other developed countries as a low-risk, highly beneficial procedure that is best performed in infancy using a local anesthetic. Infant MC should appear on the check-list of decisions responsible parents need to make for their children 
Table 1. A comprehensive risk-benefit analysis of infant male circumcision.

\begin{tabular}{|c|c|c|c|}
\hline $\begin{array}{l}\text { Risks from not circumcising } \\
\text { Condition }\end{array}$ & $\begin{array}{l}\text { Level of } \\
\text { evidence }\end{array}$ & $\begin{array}{c}\text { Fold } \\
\text { increase }\end{array}$ & $\mathrm{NNT}^{\dagger}$ \\
\hline Urinary tract infection (infants) & $1++$ & 10 & 50 \\
\hline Urinary tract infections (lifetime) & $2+$ & 5 & 4 \\
\hline Pyelonephritis (infants) & $2+$ & 10 & 100 \\
\hline -with concurrent bacteraemia & $2+$ & 20 & 1000 \\
\hline -childhood hypertension & 2 & - & 1500 \\
\hline -end-stage renal disease (lifetime) & 2 & - & 500 \\
\hline Candidiasis & 2 & 2 & 10 \\
\hline Prostate cancer & 2 & $1.5-2$ & 6 \\
\hline Balanitis & $2++$ & 3 & 10 \\
\hline Phimosis & $1++$ & infinite & 10 \\
\hline High-risk HPV & $1++$ & 3 & 2 \\
\hline Genital herpes (HSV-2) & $1+$ & 1.3 & 5 \\
\hline Syphilis & $1+$ & 3 & 200 \\
\hline HIV infection & $1++$ & $3-8$ & 1000 \\
\hline Penile cancer & $1++$ & $>20$ & 1000 \\
\hline \multicolumn{4}{|l|}{ In female partner } \\
\hline Cervical cancer & $1++$ & 4 & - \\
\hline Chlamydia & $2+$ & 4 & - \\
\hline HSV-2 & $2+$ & 2 & - \\
\hline Bacterial vaginosis & $1+$ & 2 & - \\
\hline
\end{tabular}

Thus risk in an uncircumcised male of developing a condition requiring medical attention over their lifetime $=1$ in 2 .

\begin{tabular}{lcc}
\hline $\begin{array}{l}\text { Risks associated with medical } \\
\text { circumcision in infancy } \\
\text { condition }\end{array}$ & Fold-increase & $\mathrm{NNH}$ \\
\hline $\begin{array}{l}\text { Local brusing at injection site } \\
\text { if dorsal nerve block used }\end{array}$ & $0.25^{* *}$ & 4 \\
$\begin{array}{l}\text { Infection (local) } \\
\text { Infection (systemic) }\end{array}$ & 0.002 & 600 \\
$\begin{array}{l}\text { Excessive bleeding } \\
\text { Need for repeat surgery } \\
\text { (if skin bridges or too little } \\
\text { foreskin removed) }\end{array}$ & 0.0002 & 4000 \\
Loss of penis & 0.001 & 1000 \\
Death & Close to zero & $>1$ million \\
\begin{tabular}{l} 
Loss of penile sensitivity \\
\hline
\end{tabular} & Close to zero & $>1$ million \\
\hline
\end{tabular}

*As per Scottish Intercollegiate Guidelines Network (SIGN) grading system for evidence-based guidelines [9], which ranges from $1++$ (highest) to 4 (lowest). Values shown are based on statistics for USA (for source data see review [7] and references cited in the present article). Abbreviations: ${ }^{\dagger} \mathrm{NNT}$, number needed to treat, i.e., approximate number of males who need to be circumcised to prevent one case of each condition associated with lack of circumcision. ${ }^{\dagger+} \mathrm{NNH}$, number needed to harm, i.e., approximate number of males that need to be circumcised to see one of each particular (mostly minor) adverse effect. ${ }^{* *}$ The minor bruising (from this method only) disappears naturally without any need for medical intervention, so is not included in overall calculation of easily-treatable risks.
Table 2. Some early childhood health interventions.

Breast-feeding
Immunization according to recommended vacciantion schedule
against hepatitis B, rotavirus, whooping cough, measles, rubella,
tetanus, mumps, polio, diphtheria, hemophilus influenzae type B,
chickenpox
Circumcision if male, ideally in early infancy
Nutritional food for age according to recommendations
When placed in motor vehicle, safe, rear-facing baby capsule
Safe environment-stairs barricaded, dangerous object out of reach, etc.
Prevention of over-heating or cooling
Love, nurturing, education, exercise, etc.

(Table 2). The major factors discouraging infant MC are probably biased information often provided to young parents, a ban on performing infant MC in most public hospitals in Australia, withdrawal of Medicaid funding in a growing number of states in the USA $[198,199]$, and in Australia a low Medicare rebate which makes infant MC unaffordable for low-income families. Each of these issues needs to be addressed by governments and health authorities. Further research on MC in Australia and other developed countries is to be encouraged.

\section{ACKNOWLEDGEMENTS}

There was no funding for this work and no conflicts of interest.

BJM was involved with the conception, information retrieval and writing of the initial draft of the manuscript. All other authors provided important input and suggestions for changes to the initial draft.

\section{REFERENCES}

[1] Circumcision Foundation of Australia (2010). http://www.circumcisionaustralia.org

[2] Cooper, D.A., Wodak, A.D. and Morris, B.J. (2010) The case for boosting infant male circumcision in the face of rising heterosexual transmission of HIV. The Medical Journal of Australia, 193, 318-319.

[3] Morris, B.J. (2007) Why circumcision is a biomedical imperative for the 21st Century. BioEssays, 29, 11471158. doi:10.1002/bies.20654

[4] Smith, D.K., Taylor, A., Kilmarx, P.H., et al. (2010) Male circumcision in the United States for the prevention of HIV infection and other adverse health outcomes: Report from a CDC consultation. Public Health Reports, 125, 72-82.

[5] Tobian, A.A., Gray, R.H. and Quinn, T.C. (2010) Male circumcision for the prevention of acquisition and transmission of sexually transmitted infections: The case for neonatal circumcision. Archives of Pediatrics \& Adolescent Medicine, 164, 78-84. 
doi:10.1001/archpediatrics.2009.232

[6] Macdonald, A., Humphreys, J. and Jaffe, H.W. (2008) Prevention of HIV transmission in the United Kingdom: What is the role of male circumcision? Sexually Transmitted Infections, 84, 158-160. doi:10.1136/sti.2008.029934

[7] Morris, B.J. (2010) Circumcision: An evidence-based appraisal-Medical, health and sexual (a review with 1023 references). http://www.circinfo.net

[8] Darby, R. (2011) Infant circumcision in Australia: A preliminary estimate, 2000-2010. The Australian and New Zealand Journal of Public Health, 35, 391-392. doi:10.1111/j.1753-6405.2011.00746.x

[9] Harbour, R. and Miller, J. (2001) A new system for grading recommendations in evidence based guidelines. British Medical Journal, 323, 334-336. doi:10.1136/bmj.323.7308.334

[10] Wiswell, T.E. (1997) Circumcision circumspection. The New England Journal of Medicine, 36, 1244-1245. doi:10.1056/NEJM199704243361709

[11] Schoen, E.J., Colby, C.J. and Ray, G.T. (2000) Newborn circumcision decreases incidence and costs of urinary tract infections in the first year of life. Pediatrics, 105, 789-793. doi:10.1542/peds.105.4.789

[12] Koyle, M.A., Barqawi, A., Wild, J., et al. (2003) Pediatric urinary tract infections: The role of fluoroquinolones. The Pediatric Infectious Disease Journal, 22, 1133-1137. doi:10.1097/01.inf.0000101849.11912.8e

[13] Chon, C.H., Lai, F.C. and Shortliffe, L.M. (2001) Pediatric urinary tract infections. Pediatric Clinics of North America, 48, 1441-1459. doi:10.1016/S0031-3955(05)70385-0

[14] Wiswell, T.E., Smith, F.R. and Bass, J.W. (1985) Circumcised male infants. Pediatrics, 75, 901-903.

[15] Wiswell, T.E. and Geschke, D.W. (1989) Risks from circumcision during the first month of life compared with those for uncircumcised boys. Pediatrics, 83, 1011-1015.

[16] Wiswell, T.E. and Hachey, W.E. (1993) Urinary tract infections and the circumcision state: An update. Clinical Pediatrics, 32, 130-134. doi:10.1177/000992289303200301

[17] Schoen, E.J., Wiswell, T.E. and Moses, S. (2000) New policy on circumcision-Cause for concern. Pediatrics, 105, 620-623. doi:10.1542/peds.105.3.620

[18] Singh-Grewal, D., Macdessi, J. and Craig, J. (2005) Circumcision for the prevention of urinary tract infections in boys: A systematic review of randomized trials and observational studies. Archives of Disease in Childhood, 90, 853-858. doi:10.1136/adc.2004.049353

[19] Nayir, A. (2001) Circumcision for the prevention of significant bacteriuria in boys. Pediatric Nephrology, 16, 1129-1134. doi:10.1007/s004670100044

[20] Craig, J.C., Knight, J.F., Sureshkumar, P., et al. (1996) Effect of circumcision on incidence of urinary tract infection in preschool boys. Journal of Pediatrics, 128, 23-27. doi:10.1016/S0022-3476(96)70423-7

[21] Zorc, J.J., Kiddoo, D.A. and Shaw, K.N. (2005) Diagno- sis and management of pediatric urinary tract infections. Clinical Microbiology Reviews, 18, 417-422. doi:10.1128/CMR.18.2.417-422.2005

[22] Coulthard, M.G., Lambert, H.J. and Keir, M.J. (1997) Occurrence of renal scars in children after their first referral for urinary tract infection. British Medical Journal, 315, 918-919. doi:10.1136/bmj.315.7113.918

[23] Spach, D.H., Stapleton, A.E. and Stamm, W.E. (2012) Lack of circumcision increases the risk of urinary tract infections in young men. Journal of the American Medical Association, 267, 679-681. doi:10.1001/jama.1992.03480050083029

[24] Morris, B.J. and Cox, G. (2011) Current medical evidence favours male circumcision. In: Bolnick, D.A., Koyle, M.A. and Yosha, A., Eds., Surgical Guide to Circumcision, Springer, London.

[25] Zorc, J.J., Levine, D.A., Platt, S.L., et al. (2005) Clinical and demographic factors associated with urinary tract infection in young febrile infants. Pediatrics, 116, 644-648. doi:10.1542/peds.2004-1825

[26] Shaikh, N., Morone, N.E., Bost, J.E., et al. (2008) Prevalence of urinary tract infection in childhood: A meta-analysis. The Pediatric Infectious Disease Journal, 27, 302-308. doi:10.1097/INF.0b013e31815e4122

[27] Hsiao, A.L., Chen, L. and Baker, M.D. (2006) Incidence and predictors of serious bacterial infections among 57to 180-day-old infants. Pediatrics, 117, 1695-1701. doi:10.1542/peds.2005-1673

[28] Rushton, H.G. (1997) Urinary tract infections in children. Epidemiology, evaluation, and management. Pediatric Clinics of North America, 44, 1133-1169. doi:10.1016/S0031-3955(05)70551-4

[29] Rushton, H.G. and Majd, M. (1992) Dimercaptosuccinic acid renal scintigraphy for the evaluation of pyelonephritis and scarring: A review of experimental and clinical studies. Journal of Urology, 148, 1726-1732.

[30] Wiswell, T.E. (2000) The prepuce, urinary tract infections, and the consequences. Pediatrics, 105, 8602. doi:10.1542/peds.105.4.860

[31] Jacobson, S.H., Eklof, O., Eriksson, C.G., et al. (1989) Development of hypertension and uraemia after pyelonephritis in childhood: 27 year follow up. British Medical Journal, 16, 703-706. doi:10.1136/bmj.299.6701.703

[32] Shim, Y.H., Lee, J.W. and Lee, S.J. (2009) The risk factors of recurrent urinary tract infection in infants with normal urinary systems. Pediatric Nephrology, 24, 309312. doi:10.1007/s00467-008-1001-0

[33] Conway, P.H., Cnaan, A., Zaoutis, T., et al. (2007) Recurrent urinary tract infections in children: Risk factors and association with prophylactic antimicrobials. Journal of the American Medical Association, 298, 179-186. doi:10.1001/jama.298.2.179

[34] Rushton, H.G. (1997) The evaluation of acute pyelonephritis and renal scarring with technetium $99 \mathrm{~m}$ dimercaptosuccinic acid renal scintigraphy: Evolving concepts and future directions. Pediatric Nephrology, 11, 108-120. doi:10.1007/s004670050243 
[35] Schoen, E.J. (2005) Circumcision for preventing urinary tract infections in boys: North American view. Archives of Disease in Childhood, 90, 772-773. doi:10.1136/adc.2004.066761

[36] Price, L.B., Liu, C.M., Johnson, K.E., et al. (2010) The effects of circumcision on the penis microbiome. PLoS One, 5, e8422. doi:10.1371/journal.pone.0008422

[37] Oster, J. (1968) Further fate of the foreskin: Incidence of preputial adhesions, phimosis and smegma among Danish schoolboys. Archives of Disease in Childhood, 43, 200203. doi:10.1136/adc.43.228.200

[38] Schoen, E.J. (1993) Circumcision updated-Implicated? Pediatrics, 92, 860-861.

[39] Xu, B. and Goldman, H. (2008) Newborn circumcision in Victoria, Australia: Reasons and parental attitudes. Australian and New Zealand Journal of Surgery, 78, 10191022. doi:10.1111/j.1445-2197.2008.04723.x

[40] Kalcev, B. (1964) Circumcision and personal hygiene in school boys. Medical Officer, 112, 171-173.

[41] O’Farrell, N., Quigley, M. and Fox, P. (2005) Association between the intact foreskin and inferior standards of male genital hygiene behaviour: A cross-sectional study. International Journal of STD \& AIDS, 16, 556-559. doi:10.1258/095646205467915

[42] O’Farrell, N., Chung, C.K. and Weiss, H.A. (2008) Foreskin length in uncircumcised men is associated with subpreputial wetness. International Journal of STD \& AIDS, 19, 821-823. doi:10.1258/ijsa.2008.008106

[43] Wright, J. (1970) How smegma serves the penis? Sexology, 37, 50-53.

[44] Oh, S.-J., Kim, K.D., Kim, K.M., et al. (2002) Knowledge and attitudes of Korean parents towards their son's circumcision: A nationwide questionnaire study. British Journal of Urology International, 89, 426-432. doi:10.1046/j.1464-4096.2001.01964.x

[45] Edwards, S. (1996) Balanitis and balanoposthitis: A review. Genitourinary Medicine, 72, 155-159.

[46] Herzog, L.W. and Alvarez, S.R. (1986) The frequency of foreskin problems in uncircumcised children. American Journal of Diseases of Children, 140, 254-256.

[47] Fergusson, D.M., Lawton, J.M. and Shannon, F.T. (1988) Neonatal circumcision and penile problems: An 8-year longitudinal study. Pediatrics, 81, 537-541.

[48] Fakjian, N., Hunter, S., Cole, G.W., et al. (1990) An argument for circumcision. Prevention of balanitis in the adult. Archives of Dermatology, 126, 1046-1047. doi:10.1001/archderm.1990.01670320070011

[49] Schoen, E.J. (2007) Male circumcision. In: Kandeel, F.R., Lue, T.F., Pryor, J.L. and Swerdloff, R.S., Eds., Male Sexual Dysfunction. Pathophysiology and Treatment, Informa, New York, 95-107.

[50] Kiss, A., Kiraly, L., Kutasy, B., et al. (2005) High incidence of balanitis xerotica obliterans in boys with phimosis: Prospective 10-year study. Archives of Dermatology, 22, 305-308. doi:10.1111/j.1525-1470.2005.22404.x

[51] Yardley, I.E., Cosgrove, C. and Lambert, A.W. (2007)
Paediatric preputial pathology: Are we circumcising enough? Annals of the Royal College of Surgeons of England, 89, 62-65. doi:10.1308/003588407X160828

[52] Letendre, J., Barrieras, D., Franc-Guimond, J., et al. (2009) Topical triamcinolone for persistent phimosis. Journal of Urology, 182, 1759-1763. doi:10.1016/j.juro.2009.03.016

[53] Morris, B.J. and Castellsague, X. (2011) The role of circumcision in the preventing STIs. In: Gross, G.E. and Tyring, S.K., Eds., Sexually Transmitted Infections and Sexually Transmitted Diseases, Springer-Verlag, Berlin, Heidelberg, 715-739. doi:10.1007/978-3-642-14663-3_54

[54] Weiss, H.A., Thomas, S.L., Munabi, S.K., et al. (2006) Male circumcision and risk of syphilis, chancroid, and genital herpes: A systematic review and meta-analysis. Sexually Transmitted Infections, 82, 101-109. doi:10.1136/sti.2005.017442

[55] Larke, N., Thomas, S.L., Dos Santos Silva, I., et al. (2011) Male circumcision and human papillomavirus infection in men: A systematic review and meta-analysis. Journal of Infectious Diseases, 204, 1375-1390. doi:10.1093/infdis/jir523

[56] Fergusson, D.M., Boden, J.M. and Horwood, L.J. (2006) Circumcision status and risk of sexually transmitted infection in young adult males: An analysis of a longitudinal birth cohort. Pediatrics, 118, 1971-1977. doi:10.1542/peds.2006-1175

[57] Dickson, N.P., van Roode, T., Herbison, P., et al. (2008) Circumcision and risk of sexually transmitted infections in a birth cohort. Journal of Pediatrics, 152, 383-387. doi:10.1016/j.jpeds.2007.07.044

[58] Dickson, N., van Roode, T. and Paul, C. (2005) Herpes simplex virus type 2 status at age 26 is not related to early circumcision in a birth cohort. Sexually Transmitted Diseases, 32, 517-519. doi:10.1097/01.olq.0000161296.58095.ab

[59] Dickson, N.P., Ryding, J., van Roode, T., et al. (2009) Male circumcision and serologically determined human papillomavirus infection in a birth cohort. Cancer Epidemiology, Biomarkers \& Prevention, 18, 177-183. doi:10.1158/1055-9965.EPI-08-0353

[60] Lu, B., Wu, Y., Nielson, C.M., et al. (2009) Factors associated with acquisition and clearance of human papillomavirus infection in a cohort of US men: A prospective study. Journal of Infectious Diseases, 199, 362-371. doi:10.1086/596050

[61] Gray, R.H., Serwadda, D., Kong, X., et al. (2010) Male circumcision decreases acquisition and increases clearance of high-risk human papillomavirus in HIV-negative men: A randomized trial in Rakai, Uganda. Journal of Infectious Diseases, 201, 1455-1462. doi:10.1086/652184

[62] Hernandez, B.Y., Shvetsov, Y.B., Goodman, M.T., et al. (2010) Reduced clearance of penile human papillomavirus infection in uncircumcised men. Journal of Infectious Diseases, 201, 1340-1343. doi:10.1086/651607

[63] Sobngwi-Tambekou, J., Taljaard, D., Lissouba, P., et al. (2009) Effect of HSV-2 serostatus on acquisition of HIV 
by young men: Results of a longitudinal study in Orange Farm, South Africa. Journal of Infectious Diseases, 199, 958-964. doi:10.1086/597208

[64] Tobian, A.A.R., Charvat, B., Ssempijja, V., et al. (2009) Factors associated with the prevalence and incidence of herpes simplex virus type 2 infection among men in Rakai, Uganda. Journal of Infectious Diseases, 199, 945949. doi:10.1086/597074

[65] Tobian, A.A.R., Serwadda, D., Quinn, T.C., et al. (2009) Male circumcision for the prevention of HSV-2 and HPV infections and syphilis. The New England Journal of Medicine, 360, 1298-1309. doi:10.1056/NEJMoa0802556

[66] Tobian, A.A.R., Kong, X., Gravitt, P.E., et al. (2011) Male circumcision and anatomic sites of penile human papillomavirus in Rakai, Uganda. International Journal of Cancer, 129, 2970-2975. doi:10.1002/ijc.25957

[67] Gray, R.H. (2009) Infectious disease: Male circumcision for preventing HPV infection. Nature Reviews Urology, 6 , 298-299. doi:10.1038/nrurol.2009.96

[68] Serwadda, D., Wawer, M.J., Makumbi, F., et al. (2010) Circumcision of HIV-infected men: Effects on high-risk human papillomavirus infections in a randomized trial in Rakai, Uganda. Journal of Infectious Diseases, 201, 1463-1469. doi:10.1086/652185

[69] Viscidi, R.P. and Shah, K.V. (2010) Adult male circumcision: Will it reduce disease caused by human papillomavirus? Journal of Infectious Diseases, 201, 1447-1449. doi:10.1086/652186

[70] Auvert, B., Sobngwi-Tambekou, J., Cutler, E., et al. (2009) Effect of male circumcision on the prevalence of high-risk human papillomavirus in young men: Results of a randomized controlled trial conducted in orange farm. South Africa. Journal of Infectious Diseases, 199, 14-19. doi:10.1086/595566

[71] Backes, D.M., Bleeker M.C., Meijer C.J., et al. (2011) Male circumcision is associated with a lower prevalence of human papillomavirus-associated penile lesions among Kenyan men. International Journal of Cancer [Epub ahead of print]. doi:10.1002/ijc.26196

[72] Van Wagoner, N.J., Geisler, W.M., Sizemore, J.M. Jr., et al. (2010) Herpes simplex virus in African American heterosexual males: The roles of age and male circumcision. Sexually Transmitted Diseases, 37, 217-222. doi:10.1097/OLQ.0b013e3181c17b65

[73] Bailey, R.C. and Mehta, S.D. (2009) Circumcision's place in the vicious cycle involving herpes simplex virus type 2 and HIV. Journal of Infectious Diseases, 199, 923-925. doi:10.1086/597209

[74] Gray, R.H., Kigozi, G., Serwadda, D., et al. (2007) Male circumcision for HIV prevention in men in Rakai, Uganda: A randomised trial. Lancet, 369, 657-666. doi:10.1086/597209

[75] Gray, R.H., Serwadda, D., Tobian, A.A.R., et al. (2009) Effects of genital ulcer disease and herpes simplex virus type 2 on the efficacy of male circumcision for HIV prevention: Analyses from the Rakai trials. PLoS Medicine, 6, e1000187. doi:10.1371/journal.pmed.1000187

[76] Waskett, J.H., Morris, B.J. and Weiss, H.A. (2009) Errors in meta-analysis by Van Howe. International Journal of STD \& AIDS, 20, 216-218. doi:10.1258/ijsa.2009.008126

[77] Cunningham, A.L., Taylor, R., Taylor, J., et al. (2006) Prevalence of infection with herpes simplex virus types 1 and 2 in Australia: A nationwide population-based survey. Sexually Transmitted Infections, 82, 164-168. doi:10.1136/sti.2005.016899

[78] Ferris, J.A., Richters, J., Pitts, M.K., et al. (2010) Circumcision in Australia: Further evidence on its effects on sexual health and wellbeing. The Australian and New Zealand Journal of Public Health, 34, 160-164. doi:10.1111/j.1753-6405.2010.00501.x

[79] Agius, P.A., Pitts, M.K., Smith, A.M., et al. (2010) Sexual behaviour and related knowledge among a representative sample of secondary school students between 1997 and 2008. The Australian and New Zealand Journal of Public Health, 34, 467-481. doi:10.1111/j.1753-6405.2010.00593.x

[80] Kang, M., Rochford, A., Johnston, V., et al. (2006) Prevalence of Chlamydia trachomatis infection among "high risk” young people in New South Wales. Sexual Health, 3, 253-254. doi:10.1071/SH06025

[81] Baldwin, S.B., Wallace, D.R., Papenfuss, M.R., et al. (2004) Condom use and other factors affecting penile human papilloma virus detection in men attending a sexually transmitted disease clinic. Sexually Transmitted Diseases, 31, 601-607. doi:10.1097/01.olq.0000140012.02703.10

[82] Nielson, C.M., Harris, R.B., Dunne, E.F., et al. (2007) Risk factors for anogenital human papillomavirus infection in men. Journal of Infectious Diseases, 196, 11371145. doi:10.1086/521632

[83] Castellsague, X., Bosch, F.X., Munoz, N., et al. (2002) Male circumcision, penile human papillomavirus infection, and cervical cancer in female partners. The New England Journal of Medicine, 346, 1105-1112. doi:10.1056/NEJMoa011688

[84] Mugo, N., Dadabhai, S.S., Bunnell, R., et al. (2011) Prevalence of herpes simplex virus type 2 infection, human immunodeficiency virus/herpes simplex virus type 2 coinfection, and associated risk factors in a national, population-based survey in Kenya. Sexually Transmitted Diseases, 38, 1059-1066. doi:10.1097/OLQ.0b013e31822e60b6

[85] Low, N., Broutet, N., Adu-Sarkodie, Y., et al. (2006) Global control of sexually transmitted infections. Lancet, 368, 2001-2016. doi:10.1016/S0140-6736(06)69482-8

[86] Sanchez, T., Finlayson, T., Drake, A., et al. (2006) Human immunodeficiency virus (HIV) risk, prevention, and testing behaviors-United States, National HIV Behavioral Surveillance System: Men who have sex with men, November 2003-April 2005. MMWR Surveillance Summaries, 55, 1-16.

[87] Beckman, L.J., Harvey, S.M. and Tiersky, L.A. (1996) Attitudes about condoms and condom use among college students. The Journal of American College Health, 44, 243-249. doi:10.1080/07448481.1996.9936851

[88] Anderson, J.E., Wilson, R., Doll, L., et al. (1999) Con- 
dom use and HIV risk behaviors among US adults: Data from a national survey. Family Planning Perspectives, 31, 24-28. doi:10.2307/2991553

[89] Jadack, R.A., Yuenger, J., Ghanem, K.G., et al. (2006) Polymerase chain reaction detection of Y-chromosome sequences in vaginal fluid of women accessing a sexually transmitted disease clinic. Sexually Transmitted Diseases, 33, 22-25. doi:10.1097/01.olq.0000194600.83825.81

[90] Auvert, B., Taljaard, D., Lagarde, E., et al. (2005) Randomized, controlled intervention trial of male circumcision for reduction of HIV infection risk: The ANRS 1265 Trial. PLoS Medicine, 2, 1112-1122. doi:10.1371/journal.pmed.0020298

[91] Bailey, R.C., Moses, S., Parker, C.B., et al. (2007) Male circumcision for HIV prevention in young men in Kisumu, Kenya: A randomised controlled trial. Lancet, 369, 643-656. doi:10.1016/S0140-6736(07)60312-2

[92] Siegfried, N., Muller, M., Deeks, J.J., et al. (2009) Male circumcision for prevention of heterosexual acquisition of HIV in men. Cochrane Database of Systematic Reviews, CD003362, 38.

[93] Weiss, H.A., Halperin, D., Bailey, R.C., et al. (2008) Male circumcision for HIV prevention: From evidence to action? AIDS, 22, 567-574. doi:10.1097/QAD.0b013e3282f3f406

[94] Mills, E., Cooper, C., Anema, A., et al. (2008) Male circumcision for the prevention of heterosexually acquired HIV infection: A meta-analysis of randomized trials involving 11,050 men. HIV Medicine, 9, 332-335. doi:0.1111/j.1468-1293.2008.00596.x

[95] Byakika-Tusiime, J. (2008) Circumcision and HIV infection: Assessment of causality. AIDS and Behavior, 12, 835-841. doi:10.1007/s10461-008-9453-6

[96] Gebremedhin, S. (2010) Assessment of the protective effect of male circumcision from HIV infection and sexually transmitted diseases: Evidence from 18 demographic and health surveys in sub-Saharan Africa. African Journal of Reproductive Health, 14, 105-113.

[97] Morris, B.J. and Wamai, R.G. (2011) Biological basis for the protective effect conferred by male circumcision against HIV infection. International Journal of STD \& AIDS (in press).

[98] Hill, B.A. (1965) The environment and disease: Association or causation? Proceedings of the Royal Society of Medicine, 58, 295-300.

[99] Bailey, R.C., Moses, S., Parker, C.B., et al. (2008) The protective effect of male circumcision is sustained for at least 42 months: Results from the Kisumu, Kenya Trial. XVII International AIDS Conference, 2008, THAC05.

[100] Bailey, R.C., Moses, S., Parker, C.B., et al. (2010) The protective effect of adult male circumcision against HIV acquisition is sustained for at least 54 months: Results from the Kisumu, Kenya trial. XVIII International AIDS Conference, Vienna, 18-23 July 2010.

[101] Gray, R., Kigozi, G., Kong, X., et al. (2012) The effectiveness of male circumcision for HIV prevention and effects on risk behaviors in a post-trial follow up study in Rakai, Uganda. AIDS [Epub ahead of print].
[102] Fiore, A.E., Shay, D.K., Penina Haber, P., et al. (2007) Prevention and control of influenza. Recommendations of the Advisory Committee on Immunization Practices (ACIP). Centers for Disease Control and Prevention-Mortality and Morbidity Weekly Report, 56, 1-54.

[103] Kelly, H., Carville, K., Grant, K., et al. (2009) Estimation of influenza vaccine effectiveness from routine surveillance data. PLoS One, 4, e5079. doi:10.1371/journal.pone.0005079

[104] World Health Organization and UNAIDS (2007) New data on male circumcision and HIV prevention: Policy and programme implications.

http://who.int/hiv/mediacentre/MCrecommendations_en. pdf

[105] Auvert, B., Taljaard, D., Rech, D., et al. (2011) Effect of the Orange Farm (South Africa) male circumcision roll-out (ANRS-12126) on the spread of HIV. 6th IAS Conference on HIV Pathogenesis, Treatment and Prevention, Rome, 17-20 July.

[106] Telzak, E.E., Chiasson, M.A., Bevier, P.J., et al. (1993) HIV-1 seroconversion in patients with and without genital ulcer disease: A prospective study. Annals of Internal Medicine, 119, 1181-1186.

[107] Warner, L., Ghanem, K.G., Newman, D.R., et al. (2009) Male circumcision and risk of HIV infection among heterosexual African American men attending Baltimore sexually transmitted disease clinics. Journal of Infectious Diseases, 199, 59-65. doi:10.1086/595569

[108] Sullivan, P.S., Kilmarx, P.H., Peterman, T.A., et al. (2007) Male circumcision for prevention of HIV transmission: What the new data mean for HIV prevention in the United States. PLoS Medicine, 4, 1162-1166. doi:10.1371/journal.pmed.0040223

[109] Centers for Disease Control and Prevention (2011) Diagnoses of HIV infection and AIDS in the United States and Dependent Areas.

http://www.cdc.gov/hiv/surveillance/resources/reports/20 08report/

[110] National Centre for HIV Eidemiology and Clinical Research. HIV, viral hepatitis and sexually transmissible infections in Australia. Annual Surveillance Report. http://www.med.unsw.edu.au/NCHECRweb.nsf/resources /2011/\$file/KIRBY_ASR2011.pdf.

[111] Centers for Disease Control and Prevention (2008) HIV/AIDS science facts. Male circumcision and risk for HIV transmission and other health conditions: Implications for the United States.

http://www.cdc.gov/hiv/resources/factsheets/circumcision .htm

[112] Sansom, S.L., Prabhu, V.S., Hutchinson, A.B., et al. (2010) Cost-effectiveness of newborn circumcision in reducing lifetime HIV risk among US males. PLoS One, 5, e8723. doi:10.1371/journal.pone.0008723

[113] Templeton, D.J., Jin, F., Mao, L., et al. (2009) Circumcision and risk of HIV infection in Australian homosexual men. AIDS, 23, 2347-2351. doi:10.1097/QAD.0b013e32833202b8

[114] Millett, G.A., Flores, S.A., Marks, G., et al. (2008) Cir- 
cumcision status and risk of HIV and sexually transmitted infections among men who have sex with men: A metaanalysis. JAMA, 300, 1674-1684. doi:10.1001/jama.300.14.1674

[115] Wiysonge, C.S., Kongnyuy, E.J., Shey, M., et al. (2011) Male circumcision for prevention of homosexual acquisition of HIV in men. Cochrane Database of Systematic Reviews, 6, CD007496. doi:10.1002/14651858.CD007496.pub2

[116] Anderson, J., Wilson, D., Templeton, D.J., et al. (2009) Cost-effectiveness of adult circumcision in a resourcerich setting for HIV prevention among men who have sex with men. Journal of Infectious Diseases, 200, 1803-1812. doi:10.1086/648472

[117] Virgin, H.W. and Walker, B.D. (2010) Immunology and the elusive AIDS vaccine. Nature, 464, 224-231. doi:10.1038/nature08898

[118] Morris, B.J. and Rose, B.R. (2007) Cervical screening in the 21st Century: The case for human papillomavirus testing of self-collected specimens. Clinical Chemistry and Laboratory Medicine, 45, 577-591. doi:10.1515/CCLM.2007.127

[119] Bosch, F.X., Albero, G. and Castellsagué, X. (2009) Male circumcision, human papillomavirus and cervical cancer: From evidence to intervention. Journal of Family Planning and Reproductive Health Care, 35, 5-7. doi:10.1783/147118909787072270

[120] Drain, P.K., Halperin, D.T., Hughes, J.P., et al. (2006) Male circumcision, religion, and infectious diseases: An ecologic analysis of 118 developing countries. BMC Infectious Diseases, 6, 172. doi:10.1186/1471-2334-6-172

[121] Wawer, M.J., Tobian, A.A.R., Kigozi, G., et al. (2011) Effect of circumcision of HIV-negative men on transmission of human papillomavirus to HIV-negative women: A randomised trial in Rakai, Uganda. Lancet, 377, 209-218. doi:10.1016/S0140-6736(10)61967-8

[122] Goldie, S.J., Kohli, M., Grima, D., et al. (2004) Projected clinical benefits and cost-effectiveness of a human papillomavirus 16/18 vaccine. Journal of the National Cancer Institute, 96, 604-615. doi:10.1093/jnci/djh104

[123] Garnett, G.P., Kim, J.J., French, K., et al. (2006) Chapter 21: Modelling the impact of HPV vaccines on cervical cancer and screening programmes. Vaccine, 24, 178-186. doi:10.1016/j.vaccine.2006.05.116

[124] Choi, Y.H., Jit, M., Gay, N., et al. (2010) Transmission dynamic modelling of the impact of human papillomavirus vaccination in the United Kingdom. Vaccine, 28, 4091-4102. doi:10.1016/j.vaccine.2009.09.125

[125] Brisson, M., Van de Velde, N. and Boily, M.C. (2009) Economic evaluation of human papillomavirus vaccination in developed countries. Public Health Genomics, 12, 343-351. doi:10.1159/000214924

[126] Zelkowitz, R. (2009) Cancer. HPV casts a wider shadow. Science, 323, 580-581. doi:10.1126/science.323.5914.580

[127] Chaturvedi, A.K., Engels, E.A., Pfeiffer, R.M., et al. (2011) Human papillomavirus and rising oropharyngeal cancer incidence in the United States. Journal of Clinical Oncology, [Epub ahead of print].
[128] Cherpes, T.L., Meyne, L.A., Krohn, M.A., et al. (2003) Risk factors for infection with herpes simplex virus type 2: Role of smoking, douching, uncircumcised males, and vaginal flora. Sexually Transmitted Diseases, 30, 405410. doi:10.1097/00007435-200305000-00006

[129] Mahanta, J., Borkakoty, B., Biswas, D., et al. (2010) Circumcision and herpes simplex virus-2 infection among spouses. Sexually Transmitted Infections, 86, 487. doi:10.1136/sti.2010.046359

[130] Castellsague, X., Peeling, R.W., Franceschi, S., et al. (2005) Chlamydia trachomatis infection in female partners of circumcised and uncircumcised adult men. American Journal of Epidemiology, 162, 907-916. doi:10.1093/aje/kwi284

[131] Gray, R.H., Kigozi, G., Serwadda, D., et al. (2009) The effects of male circumcision on female partners' genital tract symptoms and vaginal infections in a randomized trial in Rakai, Uganda. American Journal of Obstetrics \& Gynecology, 200, e1-e7. doi:10.1016/j.ajog.2008.07.069

[132] Cherpes, T.L., Hillier, S.L., Meyn, L.A., et al. (2008) A delicate balance: Risk factors for acquisition of bacterial vaginosis include sexual activity, absence of hydrogen peroxide-producing lactobacilli, black race, and positive herpes simplex virus type 2 serology. Sexually Transmitted Diseases, 35, 78-83. doi:10.1097/OLQ.0b013e318156a5d0

[133] Hallett, T.B., Alsallaq, R.A., Baeten, J.M., et al. (2011) Will circumcision provide even more protection from HIV to women and men? New estimates of the population impact of circumcision interventions. Sexually Transmitted Infections, 87, 88-93. doi:10.1136/sti.2010.043372

[134] Weiss, H.A., Hankins, C.A. and Dickson, K. (2009) Male circumcision and risk of HIV infection in women: A systematic review and meta-analysis. The Lancet Infectious Diseases, 9, 669-677. doi:10.1016/S1473-3099(09)70235-X

[135] Baeten, J.M., Donnell, D., Kapiga, S.H., et al. (2010) Male circumcision and risk of male-to-female HIV-1 transmission: A multinational prospective study in African HIV-1-serodiscordant couples. AIDS, 24, 737-744. doi:10.1097/QAD.0b013e32833616e0

[136] Kochen, M. and McCurdy, S. (1980) Circumcision and risk of cancer of the penis. A life-table analysis. American Journal of Diseases of Children, 134, 484-486.

[137] Morris, B.J., Gray, R.H., Castellsague, X., et al. (2011) The strong protection afforded by circumcision against cancer of the penis. Advances in Urology, Article ID 812368, 1-21. doi:10.1155/2011/812368

[138] Larke, N.L., Thomas, S.L., Dos Santos Silva, I., et al. (2011) Male circumcision and penile cancer: A systematic review and meta-analysis. Cancer Causes Control, 22, 1097-1110. doi:10.1007/s10552-011-9785-9

[139] Miralles-Guri, C., Bruni, L., Cubilla, A.L., et al. (2009) Human papillomavirus prevalence and type distribution in penile carcinoma. Journal of Clinical Pathology, 62, 870-878. doi:10.1136/jcp.2008.063149

[140] Morris, B.J., Waskett, J. and Bailis, S.A. (2007) Case 
number and the financial impact of circumcision in reducing prostate cancer. British Journal of Urology International, 100, 5-6. doi:10.1111/j.1464-410X.2007.06875.X

[141] Masters, W.H. and Johnson, V.E. (1966) Human sexual response. Little Brown, Boston.

[142] Collins, S., Upshaw, J., Rutchik, S., et al. (2002) Effects of circumcision on male sexual function: Debunking a myth? Journal of Urology, 167, 2111-2112. doi:10.1016/S0022-5347(05)65097-5

[143] Bleustein, C.B., Fogarty, J.D., Eckholdt, H., et al. (2005) Effect of neonatal circumcision on penile neurological sensation. Urology, 65, 773-777. doi:10.1016/j.urology.2004.11.007

[144] Schober, J.M., Meyer-Bahlburg, H.F. and Dolezal, C. (2009) Self-ratings of genital anatomy, sexual sensitivity and function in men using the "Self-Assessment of Genital Anatomy and Sexual Function, Male” questionnaire. British Journal of Urology International, 103, 1096-1103. doi:10.1111/j.1464-410X.2008.08166.X

[145] Payne, K., Thaler, L., Kukkonen, T., et al. (2007) Sensation and sexual arousal in circumcised and uncircumcised men. The Journal of Sexual Medicine, 4, 667-674. doi:10.1111/j.1743-6109.2007.00471.x

[146] Fink, K.S., Carson, C.C. and de Vellis, R.F. (2002) Adult circumcision outcomes study: Effect on erectile function, penile sensitivity, sexual activity and satisfaction. Journal of Urology, 167, 2113-2116. doi:10.1016/S0022-5347(05)65098-7

[147] Son, H., Song, S.H., Kim, S.W., et al. (2010) Self-reported premature ejaculation prevalence and characteristics in Korean young males: Community-based data from an internet survey. Journal of Andrology, 31, 540-546. doi:10.2164/jandrol.110.010355

[148] Waldinger, M.D., Quinn, P., Dilleen, M., et al. (2005) A multinational population survey of intravaginal ejaculation latency time. The Journal of Sexual Medicine, 2, 492-497. doi:10.1111/j.1743-6109.2005.00070.x

[149] Waldinger, M.D., McIntosh, J. and Schweitzer, D.H. (2009) A five-nation survey to assess the distribution of the intravaginal ejaculatory latency time among the general male population. The Journal of Sexual Medicine, 6, 2888-2895. doi:10.1111/j.1743-6109.2009.01392.x

[150] Laumann, E.O., Maal, C.M. and Zuckerman, E.W. (1997) Circumcision in the United States. Prevalence, prophyactic effects, and sexual practice. Journal of the American Medical Association, 277, 1052-1057. doi:10.1001/jama.1997.03540370042034

[151] Richters, J., Smith, A.M., de Visser R.O., et al. (2006) Circumcision in Australia: Prevalence and effects on sexual health. International Journal of STD \& AIDS, 17, 547-554. doi:10.1258/095646206778145730

[152] Masood, S., Patel, H.R.H., Himpson, R.C., et al. (2005) Penile sensitivity and sexual satisfaction after circumcision: Are we informing men correctly? Urologia Internationalis, 75, 62-66. doi:10.1159/000085930

[153] Kigozi, G., Watya, S., Polis, C.B., et al. (2008) The effect of male circumcision on sexual satisfaction and function, results from a randomized trial of male circumcision for human immunodeficiency virus prevention, Rakai, Uganda. British Journal of Urology International, 101, 65-70. doi:10.1111/j.1464-410X.2007.07369.X

[154] Krieger, J.N., Mehta, S.D., Bailey, R.C., et al. (2008) Adult male circumcision: Effects on sexual function and sexual satisfaction in Kisumu, Kenya. The Journal of Sexual Medicine, 5, 2610-2622. doi:10.1111/j.1743-6109.2008.00979.x

[155] Senol, M.G., Sen, B., Karademir, K., et al. (2008) The effect of male circumcision on pudendal evoked potentials and sexual satisfaction. Acta Neurologica Belgica, 108, 90-93.

[156] Senkul, T., Iseri, C., Sen, B., et al. (2004) Circumcision in adults: Effect on sexual function. Urology, 63, 155-158. doi:10.1016/j.urology.2003.08.035

[157] Willcourt, R. (2007) Critique of: "The effect of male circumcision on sexuality” by Kim, K.D., Pang, M. British Journal of Urology International, 99, 619-622. British Journal of Urology International, 99, 1169-1170. doi:0.1111/j.1464-410X.2007.06895_3.X

[158] Waskett, J.H. and Morris, B.J. (2007) Fine-touch pressure thresholds in the adult penis. British Journal of Urology International, 99, 1551-1552. doi:10.1111/j.1464-410X.2007.06970_6.X

[159] Morris, B.J., Waskett, J.H. and Gray, R.H. (2011) Does sexual function survey in Denmark offer any support for male circumcision having an adverse effect? International Journal of Epidemiology, E-pub ahead of print Nov 28.

[160] Aydur, E., Gungor, S., Ceyhan, S.T., et al. (2007) Effects of childhood circumcision age on adult male sexual functions. International Journal of Impotence Research, 19, 424-431. doi:10.1038/sj.ijir.3901545

[161] Mao, L.M., Templeton, D.J., Crawford, J., et al. (2008) Does circumcision make a difference to the sexual experience of gay men? Findings from the Health in Men (HIM) Cohort. The Journal of Sexual Medicine, 5, 2557 2561. doi:10.1111/j.1743-6109.2008.00845.x

[162] Cortés-González, J.R., Arratia-Maqueo, J.A. and GómezGuerra, L.S. (2008) Does circumcision has an effect on female's perception of sexual satisfaction? Revista de Investigacion Clinica, 60, 227-230.

[163] Kigozi, G., Lukabwe, I., Kagaayi, J., et al. (2009) Sexual satisfaction of women partners of circumcised men in a randomized trial of male circumcision in Rakai, Uganda. British Journal of Urology International, 104, 1698-1701. doi:10.1111/j.1464-410X.2009.08683.X

[164] Williamson, M.L. and Williamson, P.S. (1988) Women’s preferences for penile circumcision in sexual partners. Journal of Sex Education \& Therapy, 14, 8-12.

[165] Wildman, R.W., Wildman, R.W., Brown, A., et al. (1976) Note on males' and females' preferences for opposite sex body parts, bust sizes, and bust-revealing clothing. Psychological Reports, 38, 485-486. doi:10.2466/pr0.1976.38.2.485

[166] Morris, B.J. and Eley, C. (2011) Male circumcision: An appraisal of current instrumentation. In: Fazel-Rezai, R., 
Ed., Biomedical Engineering, University of Rijeka, Rijeka, 315-354.

http://www.intechopen.com/articles/show/title/male-circu mcision-an-appraisal-of-current-instrumentation

[167] Schoen, E.J. (2007) Should newborns be circumcised? Yes. Canadian Family Physician, 53, 2096-2097.

[168] Mancuso, T. and Burns, J. (2009) Ethical concerns in the management of pain in the neonate. Pediatric Anesthesia, 19, 953-957. doi:10.1111/j.1460-9592.2009.03144.x

[169] Russell, C.T. and Chaseling J. (1996) Topical anaesthesia in neonatal circumcision: A study of 208 consecutive cases. Australian Family Physician, 25, 30-34.

[170] Lehr, V.T., Cepeda, E., Frattarelli, D.A., et al. (2005) Lidocaine $4 \%$ cream compared with lidocaine $2.5 \%$ and prilocaine $2.5 \%$ or dorsal penile block for circumcision. American Journal of Perinatology, 22, 231-237. doi:10.1055/s-2005-871655

[171] Kirya, C. and Werthmann, M. (1978) Neonatal circumcision and penile dorsal nerve block: A painless procedure. Journal of Pediatrics, 92, 998-1000. doi:10.1016/S0022-3476(78)80386-2

[172] Sandeman, D.J. and Dilley, A.V. (2007) Ultrasound guided dorsal penile nerve block in children. Anaesth Intensive Care, 35, 266-269.

[173] Broadman, L., Hannallah, R., Belman, B., et al. (1987) Post-circumcision analgesia; a prospective evaluation of subcutaneous ring block of the penis. Anesthesiology, 67, 399-402. doi:10.1097/00000542-198709000-00019

[174] Ross, A.K., Eck, J.B. and Tobias, J.D. (2000) Pediatric regional anesthesia: Beyond the caudal. Anesthesia \& Analgesia, 91, 16-26.

[175] Van Dijk, M., de Boer, J.B., Koot, H., et al. (2001) The association between physiological and behavioral pain measures in 0- to 3-year-old infants after major surgery. Journal of Pain and Symptom Management, 22, 600-609. doi:10.1016/S0885-3924(01)00288-3

[176] Bergqvist, L.L., Katz-Salamon, M., Hertegård, S., et al. (2009) Mode of delivery modulates physiological and behavioral responses to neonatal pain. Journal of Perinatology, 29, 44-50. doi:10.1038/jp.2008.129

[177] Sternberg, W.F., Scorr, L., Smith, L.D., et al. (2005) Long-term effects of neonatal surgery on adulthood pain behavior. Pain, 113, 347-353. doi:10.1016/j.pain.2004.11.013

[178] Laprairie, J.L. and Murphy, A.Z. (2009) Neonatal injury alters adult pain sensitivity by increasing opioid tone in the periaqueductal gray. Frontiers in Behavioral Neuroscience, 3, 1-11. doi:10.3389/neuro.08.031.2009

[179] Taddio, A., Stevens, B., Craig, K., et al. (1997) Efficacy and safety of lidocaine-prilocaine cream for pain during circumcision. The New England Journal of Medicine, 336, 1197-1201. doi:10.1056/NEJM199704243361701

[180] Cilento, B.G.J., Holmes, N.M. and Canning, D.A. (1999) Plastibell complications revisited. Clinical Pediatrics, 38, 239-242. doi:10.1177/000992289903800406

[181] Christakis, D.A., Harvey, E., Zerr, D.M., et al. (2000) A trade-off analysis of routine newborn circumcision. Pedi- atrics, 105, 246-249.

[182] Ben Chaim, J., Livne, P.M., Binyamini, J., et al. (2005) Complications of circumcision in Israel: A one year multicenter survey. Israel Medical Association Journal, 7, 368-370.

[183] Schoen, E.J., Colby, C.J. and To, T.T. (2006) Cost analysis of neonatal circumcision in a large health maintenance organization. Journal of Urology, 175, 1111-1115. doi:10.1016/S0022-5347(05)00399-X

[184] Frank, R. (2000) Comment on "Christakis D.A. et al. A trade-off analysis of routine newborn circumcision. Pediatrics 2000; 105 (Part 3): 246-249”. Pediatrics, 106, 954.

[185] Griffiths, D.M., Atwell, J.D. and Freeman, N.V. (1985) A prospective survey of the indications and morbidity of circumcision in children. European Urology, 11, 184-187.

[186] Kaplan, G.W. (1983) Complications of circumcision. Urologic Clinics of North America, 10, 543-549.

[187] Weiss, H.A., Larke, N., Halperin, D., et al. (2010) Complications of circumcision in male neonates, infants and children: A systematic review. BMC Urology, 10, 13. doi:10.1186/1471-2490-10-2

[188] Krieger, J.N., Bailey, R.C., Opeya, J.C., et al. (2007) Adult male circumcision outcomes: Experience in a developing country setting. Urologia Internationalis, 78, 235-240. doi:10.1159/000099344

[189] Walter, G. and Streimer, J. (1990) Genital self-mutilation: Attempted foreskin reconstruction. The British Journal of Psychiatry, 156, 125-127. doi:10.1192/bjp.156.1.125

[190] Rennie, S., Muula, A.S. and Westreich, D. (2007) Male circumcision and HIV prevention: Ethical, medical and public health tradeoffs in low-income countries. Journal of Medical Ethics, 33, 357-361. doi:10.1136/jme.2006.019901

[191] Benatar, M. and Benatar, D. (2003) Between prophylaxis and child abuse: The ethics of neonatal male circumcision. The American Journal of Bioethics, 3, 35-48. doi:10.1162/152651603766436216

[192] Perera, C.L., Bridgewater, F.H., Thavaneswaran, P., et al. (2009) Nontherapeutic male circumcision: Tackling the difficult issues. The Journal of Sexual Medicine, 6, 22372243. doi:10.1111/j.1743-6109.2009.01306.x

[193] MacDonald, N. (2011) Male circumcision: Get the timing right. Canadian Medical Association Journal, 183, 872. doi:10.1503/cmaj.101425

[194] Clark, P.A., Eisenman, J. and Szapor, S. (2007) Mandatory neonatal male circumcision in sub-Saharan Africa: Medical and ethical analysis. Medical Science Monitor, 12, RA205-RA213.

[195] Vawda, Y.A. and Maqutu, L.N. (2011) Neonatal circumcision-violation of children's rights or public health necessity? South African Journal of Bioethics and Law, 4, 36-42.

[196] Morris, B.J. (2010) Why medical bodies and others should not advise that circumcision should be delayed until the boy can make the decision for himself. http://www.circinfo.net/circumcision_why_you_should_n ot_delay.html 
[197] Westercamp, N. and Bailey, R.C. (2007) Acceptability of male circumcision for prevention of HIV/AIDS in subSaharan Africa: A review. AIDS and Behavior, 11, 341355. doi:10.1007/s10461-006-9169-4

[198] Leibowitz, A.A., Desmond, K. and Belin, T. (2009) Determinants and policy implications of male circumcision in the United States. The American Journal of Public Health, 99, 138-145. doi:0.2105/AJPH.2008.134403

[199] Morris, B.J., Bailis, S.A., Waskett, J.H., et al. (2009) Medicaid coverage of newborn circumcision: A health parity right of the poor. American Journal of Public Health, 99, 969-971. doi:10.2105/AJPH.2009.161281 